\title{
Application of A* (A Star) Algorithm on Automation of Trash Can
}

\author{
Taufiq Tamam, Wakhyu Dwiono, Syaefudin
}

\begin{abstract}
The industrial revolution 4.0 demands the convenience of a human life facility. Not to forget also in the cleaning service. When we will dispose of trash, we do not need to look for the trash can, it is precisely the trash can that will approach us. This smartphone-based application uses the $A$ * (A star) algorithm as the basis for its work, while for communication between smartphones with the trash can system using blue tooth. The smartphone sends its coordinate position through the Global Positioning System facility, then the trash can system will search for the sender's location. The experimental results show that the average stopping distance indoors without barrier is 7.03 meters with an average time response of 25.3 seconds, the average stopping distance in the room with a barrier of 7.2 meters with the average response time 3.6 seconds average, stopping distance outdoor without a barrier of 5.7 meters with an average response time of 258.3 seconds, and the average outdoor stopping distance with a barrier of 2.73 meters with a response an average time of 141.3 seconds.
\end{abstract}

Index Terms: A* Algorithm, Bluetooth, Global Positioning System, Smartphone, Trash Can,

\section{INTRODUCTION}

The industrial revolution in the world is divided into four phases. Industrial revolution 1.0 is characterized by the invention of a steam engine to drive work equipment (production machinery) which originally used human or animal power, such as train, sailboats. The industrial revolution 2.0 was marked by the discovery of electrical energy that prompted the discovery of other technologies such as lights, telegraph machines, and conveyor belts. The industrial revolution 3.0 appeared in the early 20th century has spawned information technology and production processes that are controlled automatically using a Programmable Logic Controller (PLC) or computer-based automation system. The industrial revolution 4.0 is currently characterized by the rise of digital technology and internet telecommunications that impact on human life worldwide (Schwab, 2017). A* (A star) algorithm is one algorithm that can be used to find the fastest/shortest route. By using the manhattan distance heuristic function, this algorithm can be simulated to find the fastest distance in jammed road conditions (Syukriyah, 2016). The limitations of remote control functionality that can only work for one particular device can be solved by using an electronic device with an integrated bluetooth intermediary on Android and Arduino (Rahmiati, 2014). In the remote control of an unmanned drone, a Global Positioning System (GPS) is required. With this GPS system the pilot can control the condition of the drone (Kurniawan, 2015). Using of GPS indoor has a low level of accuracy. With the help of another device, a device that uses the bluetooth app, this problem can be solved (Aryasena, 2016). Computer technology is no longer just used as a means of computing and word processing (word processor), but also as a means for security system moving objects. By knowing the location coordinates of an object it will be known the exact position by putting in an online facility google map. So that in it will be known the exact location in the map. The tools used to conduct this study using GPS Tracker CT-58. While implementation is limited to the car. Results from this study can be beneficial and help the owners of private or rental car (Purnama, 2009)

\section{Material AND MethoD}

\section{Material}

Smartphone, blue tooth module, GPS module, ultrasonic sensor, arduino mega, DC motor, arduino IDE software and Android Studio software.

\section{Method}

Communication between smartphone devices with trash can system using Bluetooth media. The smartphone sends its coordinate position and is received by the trash can system. Data received by the trash can system is processed which will then activate the motor driver. The trash can system will look for the coordinates of the location of the smartphone. The trash can system will find the shortest path to reach the smartphone coordinates. Ultrasonic sensors will detect any obstacles in the process of searching for smartphone coordinates. Furthermore, by analyzing the work characteristics and suitability of each supporting component of the design idea, a solid and optimal initial design is obtained from mechanical, electronic and ergonomic aspects.

Revised Manuscript Received on September 22, 2019.

M. Taufiq Tamam, Electrical Engineering Departement, Universitas Muhammadiyah Purwokerto, Jawa Tengah, Indonesia

Wakhyu Dwiono, Electrical Engineering Departement, Universitas Muhammadiyah Purwokerto, Jawa Tengah, Indonesia

Syaefudin, Electrical Engineering Departement, Universitas Muhammadiyah Purwokerto, Jawa Tengah, Indonesia 


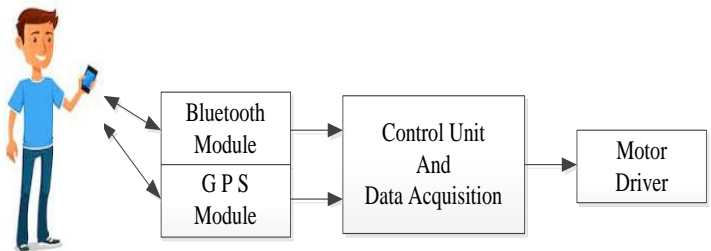

(a)

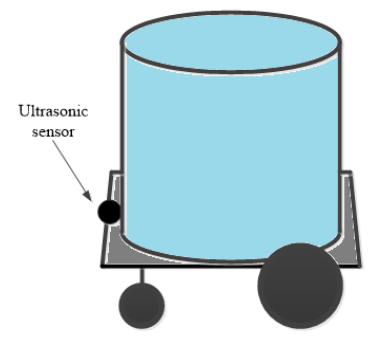

(b)

Fig. 1. (a) Block diagram (b) System design

\section{RESUlt AND DISCUSSION}

System is a form of automatic trash can application that can looking for the position of waste source. This tool consists of a GPS module that is used to locate the source position coordinates of waste, Bluetooth module as a medium of communication with the source of waste, and motor drivers that will drive the motor to the source of waste. Between the android device with the trash can system must have connected communications via Bluetooth media. The trash source, in this case is the person holding the android device, will send the coordinates of its position to the trash can system. Next, the trash can system will look for the coordinates of the position of the waste source.

Table 1 Results of Testing Bluetooth Module

\begin{tabular}{|l|c|c|c|}
\hline No. & $\begin{array}{c}\text { Distance } \\
\text { (meters) }\end{array}$ & $\begin{array}{c}\text { Time response } \\
\text { (seconds) }\end{array}$ & Information \\
\hline 1 & 2 & 1 & Without barrier \\
\hline 2 & 4 & 2 & Without barrier \\
\hline 3 & 6 & 2 & Without barrier \\
\hline 4 & 8 & 2 & Without barrier \\
\hline 5 & 10 & 2 & Without barrier \\
\hline 6 & 12 & 2 & Without barrier \\
\hline 7 & 14 & 2 & Without barrier \\
\hline 8 & 16 & 3 & Without barrier \\
\hline 9 & 20 & 1 & Without barrier \\
\hline 10 & 0,5 & 1 & With barrier \\
\hline 11 & 1 & 1 & With barrier \\
\hline 12 & 1,5 & 1 & With barrier \\
\hline 13 & 2 & 5 & With barrier \\
\hline 14 & 2,5 & 5 & With barrier \\
\hline 15 & 3 & 10 & With barrier \\
\hline
\end{tabular}

Table 1 shows the results of the Bluetooth module response test with average response duration of 1.89 seconds for the barrier less area and 3.83 seconds for areas with barrier.

\begin{tabular}{|c|c|c|c|c|c|}
\hline & \multirow{2}{*}{ Location } & \multicolumn{2}{|c|}{ GPS module } & \multicolumn{2}{|c|}{ Smartphone } \\
\hline & & Longitude & Latitude & Longitude & Lintang \\
\hline 1 & \multirow{5}{*}{ Outdoor } & 109,271949 & $-7,413783$ & 109,271965 & $-7,413695$ \\
\hline 2 & & 109,271835 & $-7,413798$ & 109,271965 & $-7,413695$ \\
\hline 3 & & 109,271850 & $-7,413736$ & 109,271888 & $-7,413846$ \\
\hline 4 & & 109,271896 & $-7,413695$ & 109,272033 & $-7,413589$ \\
\hline 5 & & 109,271903 & $-7,413845$ & 109,272033 & $-7,413589$ \\
\hline 6 & \multirow{5}{*}{ Indoor } & 109,274414 & $-7,413255$ & 109,274146 & $-7,413514$ \\
\hline 7 & & 109,274375 & $-7,413201$ & 109,274353 & $-7,413265$ \\
\hline 8 & & 109,274434 & $-7,413175$ & 109,274307 & $-7,412232$ \\
\hline 9 & & 109,274505 & $-7,413275$ & 109,274513 & $-7,413341$ \\
\hline $\begin{array}{l}1 \\
0\end{array}$ & & 109,274520 & $-7,413264$ & 109,274604 & $-7,413211$ \\
\hline
\end{tabular}

Table 2 Test Results of GPS Module

Table 2 shows the test results of GPS modules indoors and outdoors compared to existing GPS on smartphone devices. The test results show that there is difference of coordinate reading with average difference of $2.19398 \times 10-4$ meter.

Table 3 Overall System Test Results

\begin{tabular}{|c|c|c|c|c|c|c|}
\hline \multirow[b]{2}{*}{$\begin{array}{c}\text { No } \\
\text {. }\end{array}$} & \multirow[b]{2}{*}{$\begin{array}{c}\text { Testing } \\
\text { Locatio } \\
\mathbf{n}\end{array}$} & \multicolumn{2}{|c|}{ Target coordinate } & \multirow{2}{*}{$\begin{array}{l}\text { Distan } \\
\text { ce of } \\
\text { trash } \\
\text { can } \\
\text { (m) }\end{array}$} & \multirow{2}{*}{$\begin{array}{c}\text { Distan } \\
\text { ce of } \\
\text { trash } \\
\text { can } \\
\text { stoppe } \\
\text { d (m) }\end{array}$} & \multirow[b]{2}{*}{$\begin{array}{c}\text { Travel } \\
\text { Time } \\
\text { (secon } \\
\text { ds) }\end{array}$} \\
\hline & & $\begin{array}{c}\text { Longitud } \\
\mathrm{e}\end{array}$ & Latitude & & & \\
\hline 1 & \multirow{3}{*}{$\begin{array}{l}\text { Indoor } \\
\text { without } \\
\text { barrier }\end{array}$} & $\begin{array}{c}109,2728 \\
5\end{array}$ & $-7,41381$ & 9,5 & 6,5 & 30 \\
\hline 2 & & $\begin{array}{c}109,2718 \\
6\end{array}$ & $-7,41381$ & 9,5 & 7 & 32 \\
\hline 3 & & $\begin{array}{c}109,2719 \\
4\end{array}$ & $\begin{array}{c}-7,41360 \\
4\end{array}$ & 9,4 & 7,6 & 14 \\
\hline 4 & \multirow{3}{*}{$\begin{array}{l}\text { Indoor } \\
\text { with } \\
\text { barrier }\end{array}$} & 109,272 & $\begin{array}{c}-7,41388 \\
5\end{array}$ & 9,4 & 7,8 & 24 \\
\hline 5 & & $\begin{array}{c}109,2719 \\
2\end{array}$ & $\begin{array}{c}-7,41345 \\
3\end{array}$ & 8,7 & 7,8 & 18 \\
\hline 6 & & $\begin{array}{c}109,2718 \\
7\end{array}$ & $\begin{array}{c}-7,41381 \\
9\end{array}$ & 7,7 & 6 & 53 \\
\hline 7 & \multirow{2}{*}{$\begin{array}{l}\text { Outdoo } \\
r \\
\text { without } \\
\text { barrier }\end{array}$} & $\begin{array}{c}109,2746 \\
0\end{array}$ & $\begin{array}{c}-7,41331 \\
1\end{array}$ & 11,7 & 2,5 & 470 \\
\hline 8 & & $\begin{array}{c}109,2723 \\
5\end{array}$ & $-7,41371$ & 12,9 & 8,6 & 142 \\
\hline
\end{tabular}




\begin{tabular}{|c|c|c|c|c|c|c|}
\hline 9 & & $\begin{array}{c}109,2724 \\
5\end{array}$ & $-7,41369$ & 10 & 6 & 163 \\
\hline 10 & \multirow{3}{*}{$\begin{array}{l}\text { Outdoo } \\
\text { r with } \\
\text { barrier }\end{array}$} & $\begin{array}{c}109,2724 \\
1\end{array}$ & $\begin{array}{c}-7,41365 \\
8\end{array}$ & 6 & 3,3 & 71 \\
\hline 11 & & $\begin{array}{c}109,2724 \\
4\end{array}$ & $\begin{array}{c}-7,41373 \\
3\end{array}$ & 7,4 & 2,2 & 170 \\
\hline 12 & & $\begin{array}{c}109,2723 \\
3\end{array}$ & $\begin{array}{c}-7,41372 \\
4\end{array}$ & 7,5 & 2,7 & 183 \\
\hline
\end{tabular}

Table 3 shows the overall system test results. Tests are conducted in different locations, indoors and outdoors either barrier or barrierless. Barrierless indoor testing has an average stopping distance of 7.03 meters with an average response time of 25.3 seconds, while with barrier having an average stopping distance of 7.2 meters with an average response time of 3.6 seconds. Barrierless outdoor testing has an average stopping distance of 5.7 meters with an average response time of 258.3 seconds, whereas with barrier having an average stopping distance of 2.73 meters with an average response time of 141. 3 seconds. Test results show different responses, outdoor testing provides better results than indoor testing. Indoor testing gives worse results due to communication between satellites with existing GPS modules in the system hindered by buildings (walls, roofs, etc.), while in outdoor testing provides better results due to communication between satellites with modules GPS without having a hitch.

\section{CONCLUSION}

The system created in this study has been able to work in accordance with the planning, which can detect or find the source of waste and then move towards the source of the waste. From the test results can be concluded that the average distance stop indoor without a barrier of 7.03 meters with an average time response of 25.3 seconds, the average distance stopped indoor with a barrier of 7.2 meters with the response time averaging 3.6 seconds. Barrierless outdoor testing has an average stopping distance of 5.7 meters with an average response time of 258.3 seconds, whereas with barrier having an average stopping distance of 2.73 meters with an average response time of 141.3 seconds.

\section{REFERENCES}

1. Aryasena, A. Ginardi, R. V. H. Baskoro, F. (2016). Perancangan Indoor Localization Menggunakan Bluetooth Untuk Pelacakan Posisi Benda di Dalam Ruangan. JURNAL TEKNIK ITS Vol. 5, No. 2, ISSN: 2337-3539 (2301-9271 Print).

2. Kurniawan, A. P. Mutiara, G. A. Hapsari, G. I. (2015). Pengiriman Informasi GPS (Global Positioning System) Berupa Teks Melalui
Wireless pada AR Drone 2.0. e-Proceeding of Applied Science: Vol.1, No.2, Page 1022, ISSN: 2442-5826.

3. Purnama, B. E. (2009). Pemanfaatan Global Positioning System Untuk Pelacakan Objek Bergerak. Journal Speed - Sentra Penelitian Engineering dan Edukasi - Volume 2 No. 2, ISSN : 1979-9330 (Print) - 2088-0154 (Online).

4. Rahmiati, P. Firdaus, G. Fathorrahmani, N. (2014). Implementasi Sistem Bluetooth menggunakan Android dan Arduino untuk Kendali Peralatan Elektronik. Jurnal Elkomnika, Institut Teknologi Nasional Bandung, Vol. 2, No. 1.

5. Schwab, K. (2017). The Fourth Industrial Revolution. Crown Business Press.

6. Syukriyah, Y. Falahah. Solihin, H. (2016). Penerapan Algoritma A* (Star) Untuk Mencari Rute Tercepat Dengan Hambatan. Seminar Nasional Telekomunikasi dan Informatika (SELISIK), ISSN: 2503-2844.

\section{AUTHORS PROFILE}

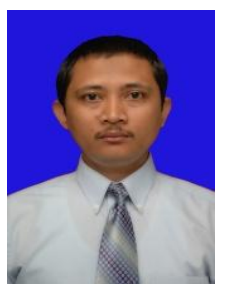

M. Taufiq Tamam, S.T., M.T. was born at Cilacap on 1970. Lecturer at Electrical Engineering Departement Universitas Muhammadiyah Purwokerto. He had completed his under graduate program has at Electrical Engineering Departement Institut Teknologi Sepuluh Nopember Surabaya (1998). He had completed his Post graduate program at the Electrical Engineering Departement Universitas Gadjah Mada Yogyakarta (2005). His Research interest is in electronics signal system. Publication article include: Design a System of Measurement of Heart Rate, Oxygen Saturation in Blood and Body Temperature with Non-invasive Method (2017), Visualization of Measurement of Heart Rate, Oxygen Saturation in Blood and Body Temperature with Non-invasive Method (2018). Member of IAENG. For academic purposes, the author can be contacted via e-mail at: tamam@ump.ac.id

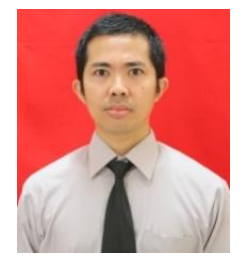

Wakhyu Dwiono, S.T., M.T. was born at Purbalingga on 1977. He is Lecturer at Electrical Engineering Department Universitas Muhammadiyah Purwokerto. He had completed his Under graduate program at Electrical Engineering Departement Universitas Diponegoro Semarang (1999). He completed his Post graduate program at the Electrical Engineering Department, Institute Teknologi Bandung (2005). His Research interest is in the field of signal and system. Publication article: Simple Implementation of Fuzzy Controller For Low Cost Microcontroller (2019). Member of IAENG. For academic purposes, the author can be contacted via e-mail at: Email: wakhyudwi@gmail.com.

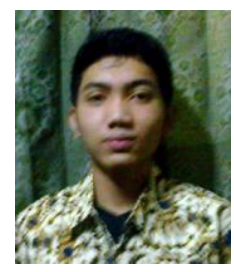

Syaefudin was born at Banyumas in 1995 Syaefudin is an undergraduate student studying at the Electrical Engineering Department, Universitas Muhammadiyah Purwokerto, For academic purposes, the author can be contacted via e-mail at: asepsyaefudin19@gmail.com 